\title{
Purification and some Properties of a Medium-Chain Acyl-Thioester Hydrolase from Lactating-Rabbit Mammary Gland which Terminates Chain Elongation in Fatty Acid Synthesis
}

\author{
By JENS KNUDSEN,* SUSAN CLARK $\uparrow$ and RAYMOND DLS† \\ *Institute of Biochemistry, Odense University, 5000 Odense, Denmark, and \\ $\dagger$ Department of Biochemistry, University Hospital and Medical School, Nottingham NG7 2UH, U.K.
}

(Received 5 July 1976)

\begin{abstract}
1. An acyl-thioester hydrolase was isolated from the cytosol of lactating-rabbit mammary gland. The purified enzyme terminates fatty acid synthesis at medium-chain $\left(\mathrm{C}_{8: 0^{-}}\right.$ $C_{12: 0}$ ) acids when it is incubated with fatty acid synthetase and rate-limiting concentrations of malonyl-CoA. These acids are characteristic products of the lactating gland. 2. The mol.wt. of the enzyme is $29000 \pm 500$ (mean \pm S.D. of three independent preparations), as estimated by polyacrylamide-gel electrophoresis in the presence of sodium dodecyl sulphate. 3. The enzyme also hydrolyses acyl-CoA esters of chain lengths $\mathrm{C}_{10: 0}-\mathrm{C}_{16: 0}$ when these are used as model substrates. The greatest activity was towards dodecanoyl-CoA, and the three preparations had specific activities of 305, 1130 and $2010 \mathrm{nmol}$ of dodecanoyl-CoA hydrolysed/min per $\mathrm{mg}$ of protein when $56 \mu \mathrm{M}$ substrate was used. 4. The way in which this enzyme controls the synthesis of medium-chain fatty acids by fatty acid synthetase is briefly discussed.
\end{abstract}

The mechanism by which chain elongation is terminated during fatty acid synthesis de novo is not fully understood. Sumper et al. (1969) have put forward a model to explain chain termination by yeast fatty acid synthetase, which releases long-chain $\left(C_{16: 0}-C_{18: 0}\right)$ fatty acids as the acyl-CoA esters. They propose that the probability of any covalently bound acyl residue forming a product by being transferred to $\mathrm{CoA}$ is determined by the relative velocities of the elongating and of the terminating transfer reactions of the synthetase. The maximum chain length synthesized is governed by an increasing interaction of the growing alkane chain with the hydrophilic enzyme protein. This leads to termination of fatty acid synthesis at $\mathrm{C}_{16: 0}$ and $\mathrm{C}_{18: 0}$ acids. The model could also explain chain termination by fatty acid synthetases from mammalian and avian tissues and from Escherichia coli, which release unesterified long-chain $\left(\mathrm{C}_{14: 0^{-}}\right.$ $C_{18: 0}$ ) fatty acids [see Vagelos (1974) for review]. With these latter synthetases, the acyltransferase transfers the acyl group to water (rather than to CoA) and so acts as an acyl-thioester hydrolase which is specific for long-chain acyl-thioesters.

Lactating-rabbit mammary gland terminates chain elongation at $\mathrm{C}_{8: 0}$ and $\mathrm{C}_{10: 0}$ fatty acids both in vivo (Carey \& Dils, 1972) and in vitro (Strong \& Dils, 1972). By contrast, purified fatty acid synthetase from

‡ Present address: Department of Physiology and Biochemistry, University of Reading, Whiteknights, Reading RG6 2AJ, U.K. this tissue only synthesizes $\mathrm{C}_{4: 0}$ and $\mathrm{C}_{16: 0}$ fatty acids in significant proportions (Carey \& Dils, 1970a). When acyl-CoA esters are used as model substrates, the acyl-thioester hydrolase activity of this synthetase is specific for $C_{14: 0}$ and $C_{16: 0}$ acyl-CoA esters (Knudsen et al., 1975). The inability of this purified synthetase to release $\mathrm{C}_{8: 0}$ and $\mathrm{C}_{10: 0}$ acids can therefore be explained by the model of Sumper et al. (1969) by the greater velocity of the elongation reaction compared with that of the acyl-thioester hydrolase for covalently bound medium-chain acyl residues.

One explanation for the synthesis of medium-chain fatty acids by lactating-rabbit mammary gland is the presence in the tissue of an acyl-thioester hydrolase which could specifically release medium-chain acids from the acyl-carrier protein or from other leaving sites of the fatty acid synthetase. We have presented preliminary evidence for the presence of this enzyme in the cytosol of lactating-rabbit mammary gland and have shown that the enzyme terminates chain lengthening even when the synthesized fatty acids were not subsequently esterified as glycerides. The crude enzyme preparation also hydrolysed acyl-CoA esters of various chain lengths when these were used as model substrates to mimic fatty acids covalently bound to fatty acid synthetase (Knudsen \& Dils, 1975; Knudsen et al., 1975). The present paper describes the purification and some of the properties of the enzyme and compares the enzyme with fatty acyl-CoA hydrolases (EC 3.1.2.2) from other tissues. 


\section{Materials and Methods}

\section{Materials}

Malonyl-CoA, NADH, NADPH, ATP, 5,5'dithiobis-(2-nitrobenzoic acid), dithiothreitol, bovine serum albumin (fraction $\mathrm{V}$, fatty acid-poor), pepsin (EC 3.4.23.1), cytochrome $c$, trypsin (type III) (EC 3.4.21.4), ovalbumin, myoglobin and sodium dodecyl sulphate were purchased from Sigma Chemical Co., St. Louis, MO, U.S.A. Acrylamide and bisacrylamide were obtained from Fluka A.G., Buchs, Switzerland, and CoA and peroxidase (EC 1.11.1.7) were from Boehringer, Mannheim, West Germany. Ultragel AcA 44 was supplied by LKB A.B., Bromma, Sweden, and Sephadex G-100 by Pharmacia Fine Chemicals A.B., Uppsala, Sweden. $\left[1-{ }^{14} \mathrm{C}\right]$ Acetic anhydride and $11{ }^{14} \mathrm{C}$-labelled fatty acids were obtained from The Radiochemical Centre, Amersham, Bucks., U.K. Pepsin (EC 3.4.23.1) was also purchased from E. Merck, Darmstadt, West Germany. All the other reagents used were of analytical purity and were obtained from E. Merck.

\section{Methods}

Acetyl-CoA and $\left[1-{ }^{14} \mathrm{C}\right]$ acetyl-CoA were prepared from acetic anhydride and from $\left[1-{ }^{14} \mathrm{C}\right]$ acetic anhydride respectively as described by Stadtman (1957). Radioactive and non-radioactive long-chain acyl-CoA esters were synthesized by the method of Sánchez et al. (1973). To synthesize the CoA esters of butyric acid, hexanoic acid and octanoic acid, the method was modified as follows (D. N. Brindley, personal communication) by converting the sodium salts of these acids into the tetraethylammonium salts before the reaction with ethyl chloroformate. Tetraethylammonium hydroxide was prepared by shaking tetraethylammonium bromide (2.1 g) with $\mathrm{Ag}_{2} \mathrm{O}$ $(3.5 \mathrm{~g})$ in $10 \mathrm{ml}$ of water for $10 \mathrm{~min}$. The $\mathrm{AgBr}$ was removed by centrifugation. A column $(5 \mathrm{~cm} \times 0.5 \mathrm{~cm})$ of Dowex $50 \mathrm{~W}\left(\mathrm{H}^{+}\right.$form) was converted into the tetraethylammonium form by applying $3 \mathrm{ml}$ of the aqueous solution of tetraethylammonium hydroxide and then washing the column with water until the eluate was pH7.0. The sodium salts of butyric acid, hexanoic acid or octanoic acid (in each case $20 \mu \mathrm{mol}$ in $0.4 \mathrm{ml}$ of water) were applied to the column. The eluate containing the tetraethylammonium salts was evaporated to dryness under $\mathrm{N}_{2}$, and the salt was dissolved in methylene chloride.

All acyl-CoA esters were analysed and purified as described by Pullman (1973). [1-14 C]Acyl-carnitine esters of chain lengths $C_{4: 0}-C_{16: 0}$ were a gift from Dr. R. Breach, Department of Biochemistry, University of Liverpool, U.K. Their ester content was determined by the method of Stern \& Shapiro (1956), and their rate of hydrolysis by purified medium-chain acyl-thioester hydrolase was measured at 3 and $10 \mu \mathrm{M}$ substrate concentrations under the assay conditions described below for the radiochemical assay of the hydrolysis of fatty acyl-CoA esters.

Acetyl-CoA carboxylase (EC 6.4.1.2) was purified from lactating-rabbit mammary gland by the method of Manning et al. (1976). Fatty acid synthetase was purified from this tissue by the method of Knudsen (1972).

\section{Enzyme purification}

Unless stated otherwise, all procedures were carried out at $4^{\circ} \mathrm{C}$. Mammary tissue (approx. $100 \mathrm{~g}$ wet wt.) from lactating rabbits (12-16 days post partum) was finely chopped with scissors. Excess of milk was removed by washing the mince with $0.25 \mathrm{M}$-potassium phosphate buffer, pH7.0, containing $1 \mathrm{~mm}$-EDTA and $0.25 \mathrm{~mm}$-dithiothreitol $(2 \mathrm{ml} / \mathrm{g}$ wet wt. of tissue). The tissue was homogenized with this buffer $(2 \mathrm{ml} / \mathrm{g}$ wet wt. of tissue) in a Potter-Elvehjem homogenizer and the homogenate was centrifuged at $105000 g_{\text {av }}$. for $2 \mathrm{~h}$ to yield the particulate-free supernatant fraction. Solid $\left(\mathrm{NH}_{4}\right)_{2} \mathrm{SO}_{4}$ was added continuously, with stirring, to this fraction. The protein precipitated between 245 and $390 \mathrm{~g}$ of $\left(\mathrm{NH}_{4}\right)_{2} \mathrm{SO}_{4}$ per litre of initial volume was collected by centrifugation at $10000 \mathrm{~g}_{\mathrm{av}}$. for $10 \mathrm{~min}$. The precipitate was dissolved in $5 \mathrm{mM}$-potassium phosphate buffer, $\mathrm{pH}$ 7.0, containing $1 \mathrm{mM}$-EDTA and $0.25 \mathrm{~mm}$-dithiothreitol and was applied to a column $(2.5 \mathrm{~cm} \times 80 \mathrm{~cm})$ of Ultragel AcA 44. The column was eluted with $0.1 \mathrm{~mm}$-potassium phosphate buffer, pH7.0, containing $1 \mathrm{~mm}$-EDTA and $0.25 \mathrm{~mm}$-dithiothreitol, and fractions $(7 \mathrm{ml})$ containing the enzyme were pooled. The enzyme was concentrated by adding $470 \mathrm{~g}$ of $\left(\mathrm{NH}_{4}\right)_{2} \mathrm{SO}_{4} /$ litre of the pooled fractions. The precipitate was dissolved in the minimum volume (about $5 \mathrm{ml}$ ) of $5 \mathrm{mM}$-potassium phosphate buffer, pH7.8, containing 1 mM-EDTA and $1 \mathrm{~mm}$-dithiothreitol and was then dialysed against 2 litres of the same buffer for $4 \mathrm{~h}$ with one change of buffer.

A portion of the dialysed sample $(20-30 \mathrm{mg}$ of protein) was applied to a preparative electrophoresis column (Shandon Scientific Co. Ltd., Willesden, London N.W.10, U.K.) of $18.8 \%$ (w/v) polyacrylamide ( $2.7 \%$ cross-linked; $4 \mathrm{~cm}$ long) which had been polymerized in $8 \mathrm{~mm}-\mathrm{Tris} / \mathrm{HCl}$ buffer, $\mathrm{pH} 7.8$, by riboflavin. The upper and lower buffer compartments contained $5 \mathrm{~mm}$-Tris/glycine buffer, pH8.5. The column was run for about $2 \mathrm{~h}$ before the enzyme was applied. Electrophoresis was carried out for 18-20h at $2^{\circ} \mathrm{C}$ with a constant current of $10 \mathrm{~mA}$ at $400 \mathrm{~V}$. The protein bands were then continuously eluted from the column with $14 \mathrm{~mm}$-Tris/ $\mathrm{HCl}$ buffer, $\mathrm{pH} 7.8$, containing $1 \mathrm{~mm}$-EDTA and $0.25 \mathrm{~mm}$-dithiothreitol, at a flow rate of $4.8 \mathrm{ml} / \mathrm{h}$. Fractions $(1.2 \mathrm{ml})$ containing medium-chain acyl-thioester hydrolase were pooled and stored at $-70^{\circ} \mathrm{C}$. 
Assay of medium-chain acyl-thioester hydrolase activity by chain-length termination in fatty acid synthesis

The purified enzyme was assayed by its ability to terminate fatty acid synthesis at medium-chain fatty acids. The incubation system (final volume $0.5 \mathrm{ml}$ ) contained $0.1 \mathrm{M}$-potassium phosphate buffer, $\mathrm{pH} 7.0$, $1 \mathrm{mM}-E D T A, \quad 100 \mu \mathrm{M}-\left[1-{ }^{14} \mathrm{C}\right]$ acetyl-CoA $\quad(5.75 \mu \mathrm{Ci} /$ $\mu \mathrm{mol}), 10 \mathrm{~mm}-\mathrm{KHCO}_{3}, 5 \mathrm{mM}-\mathrm{ATP}, 8 \mathrm{mM}-\mathrm{MgCl}_{2}$, $5 \mathrm{~mm}$-tripotassium citrate, $0.24 \mathrm{~mm}-\mathrm{NADPH}$, fatty acid synthetase purified from lactating-rabbit mammary gland $(218 \mu \mathrm{g}$, of specific activity $1.16 \mu \mathrm{mol}$ of $\mathrm{NADPH}$ oxidized/min per $\mathrm{mg}$ of protein) and purified medium-chain acyl-thioester hydrolase as shown. $\left[1-{ }^{14} \mathrm{C}\right]$ Malonyl-CoA was generated in situ by adding rate-limiting amounts of acetyl-CoA carboxylase purified from lactating-rabbit mammary gland $(10.5 \mu \mathrm{g}$, of specific activity $520 \mathrm{nmol}$ of malonyl-CoA formed/min per $\mathrm{mg}$ of protein). The mixture was incubated at $37^{\circ} \mathrm{C}$ for $10 \mathrm{~min}$ and the reaction was stopped by adding aqueous $\mathrm{NaOH}$ to a final concentration of $2.5 \mathrm{M}$. The radioactive fatty acids were extracted and were analysed by radio-g.l.c. as described by Knudsen (1976). In the absence of medium-chain acyl-thioester hydrolase this system synthesized negligible proportions of medium-chain fatty acids. All assays were performed in duplicate.

Assay of medium-chain acyl-thioester hydrolase activity with acyl-CoA esters as model substrates

(1) Spectrophotometric assay. For convenience throughout the purification procedure, the enzyme activity was assayed by measuring the release of thiol groups from dodecanoyl-CoA as model substrate. The assay mixture contained $0.4 \mathrm{M}$-Tris/ $\mathrm{HCl}$ buffer, pH7.4, 1 mm-EDTA, 0.2 mm-5,5'-dithiobis-(2-nitrobenzoic acid) and enzyme protein. It was preincubated for $3 \mathrm{~min}$ at $37^{\circ} \mathrm{C}$. The reaction was started by adding dodecanoyl-CoA (final concentration $56 \mu \mathrm{M}$; see Fig. 2) and was followed spectrophotometrically at $412 \mathrm{~nm}$. The amount of thiol released was calculated from the molar extinction coefficient $\varepsilon=1.36 \times 10^{4}$ litre $\cdot \mathrm{mol}^{-1} \cdot \mathrm{cm}^{-1}$ (Means \& Feeney, 1971).

(2) Radiochemical assay. The specificity of the purified enzyme towards acyl-CoA esters of various chain lengths when these are used as model substrates was determined by measuring the release of $\left[1-{ }^{14} \mathrm{C}\right]-$ fatty acids from the radioactive acyl-CoA esters. The assay mixture contained $0.1 \mathrm{M}$-potassium phosphate buffer, pH 7.5, 1 mM-EDTA, 1 mM-dithiothreitol, 3 or $8 \mu \mathrm{M}-\left[1-{ }^{14} \mathrm{C}\right]$ acyl-CoA esters $(0.4-1.6 \mathrm{nCi} / \mathrm{nmol})$ and albumin (as indicated). It was incubated at $37^{\circ} \mathrm{C}$ for $5 \mathrm{~min}$. The reaction was started by adding $1-4 \mu \mathrm{g}$ of enzyme protein which had been preincubated at $37^{\circ} \mathrm{C}$ for $2 \mathrm{~min}$ in $14 \mathrm{~mm}$-Tris/HCl buffer, $\mathrm{pH} 7.8$. The final volume of the reaction mixture was $0.5 \mathrm{ml}$. The reaction was stopped after $0.5-3.0 \mathrm{~min}$ with $2.0 \mathrm{ml}$ of
Dole's (1956) reagent. Unesterified ${ }^{14} \mathrm{C}$-labelled fatty acids of chain lengths $C_{8: 0}-C_{16: 0}$ were extracted by the method of Bar-Tana et al. (1971). The top phase, which contained the unesterified ${ }^{14} \mathrm{C}$-labelled fatty acids, was mixed with $10 \mathrm{ml}$ of xylene containing $4.0 \mathrm{~g}$ of 2,5-diphenyloxazole/litre and $0.1 \mathrm{~g}$ of 1,4-bis-(5phenyloxazol-2-yl)benzene/litre, and the radioactivity determined by liquid scintillation. Portions $(0.5-$ $1.0 \mathrm{ml}$ ) of the bottom phase were mixed with $10 \mathrm{ml}$ of Triton X-100/xylene $(1: 2, \mathrm{v} / \mathrm{v})$ containing $5.5 \mathrm{~g}$ of 2,5-diphenyloxazole/litre and $0.1 \mathrm{~g}$ of 1,4-bis-(5phenyloxazol-2-yl)benzene/litre. Water $(0.1-0.5 \mathrm{ml})$ was added, and the radioactivity determined by liquid scintillation. When butyryl-CoA or hexanoyl-CoA was used as substrate, the reaction was stopped by adding $0.5 \mathrm{ml}$ of $0.1 \mathrm{M}-\mathrm{HCl}$. The unesterified fatty acids were extracted four times with $1.0 \mathrm{ml}$ portions of diethyl ether and their radioactivity was determined by liquid scintillation. The recovery of $\left[{ }^{14} \mathrm{C}\right]$ butyric acid was $93 \%$. Control incubations without added enzyme were always used. All assays were performed in triplicate.

\section{Molecular weight}

The molecular weight of partly purified mediumchain acyl-thioester hydrolase was determined by gel filtration (Andrews, 1970). The molecular weight and the homogeneity of the purified enzyme was established by polyacrylamide-disc-gel electrophoresis in the presence of sodium dodecyl sulphate (Weber \& Osborn, 1969). A $10 \%(w / v)$ polyacrylamide gel was used.

\section{Protein determination}

Protein was determined by the method of Lowry et al. (1951), with bovine serum albumin as standard.

\section{Results}

\section{Enzyme purification}

Details of the purification of the enzyme are shown in Table 1. The only effective step in the final stage of the purification was found to be preparative polyacrylamide-gel electrophoresis. This increased the specific activity about 12 -fold with relatively little loss of enzyme activity. Attempts to use cellulose ionexchange chromatography or hydroxyapatite treatment at this stage of the purification were unsuccessful.

Three independent preparations of the enzyme purified by the procedures given in Table 1 had specific activities of 305,1130 and $2010 \mathrm{nmol}$ of dodecanoyl-CoA hydrolysed/min per mg of protein as determined by the spectrophotometric assay at a substrate concentration of $56 \mu \mathrm{M}$. The three preparations were homogeneous by the criterion of analytical 
Table 1. Purification of medium-chain acyt-lhioester hydrolase from mammary gland of lactaring rabbits

Details of the purification are given in the Materials and Methods section. One unit of enzyme activity is defined as $1 \mathrm{nmo}$ of dodecanoyl-CoA hydrolysed/min at a substrate concentration of $56 \mu \mathrm{M}$ in the spectrophotometric assay.

1. Particle-free supernatant

2. $\left(\mathrm{NH}_{4}\right)_{2} \mathrm{SO}_{4}$ fraction (245-390g/litre)

3. Ultragel AcA 44 eluate [concentrated by precipitation with $\left(\mathrm{NH}_{4}\right)_{2} \mathrm{SO}_{4}$ and dialysed]

4. Preparative-electrophoresis eluate

$\begin{array}{cc}\begin{array}{c}\text { Protein } \\ \text { (mg) }\end{array} & \begin{array}{c}\text { Activity } \\ \text { (units) }\end{array} \\ 2160 & 15600 \\ 280 & 5040 \\ 46.2 & 4350\end{array}$

$2.1 \quad 2380$

Specific activity
(units/mg of protein)
7.2
21.6
94.2

94.2

$\begin{array}{cc}\text { Purification } & \begin{array}{c}\text { Yield } \\ (\%)\end{array} \\ 1.0 & 100 \\ 3.0 & 39 \\ 13.1 & 26\end{array}$

157 polyacrylamide-disc-gel electrophoresis in the presence of sodium dodecyl sulphate on $10 \%(w / v)$ gels (Plate 1).

\section{Molecular weight}

The approximate mol.wt. of the enzyme as the material precipitated by $245-290 \mathrm{~g}$ of $\left(\mathrm{NH}_{4}\right)_{2} \mathrm{SO}_{4} /$ litre from the particle-free supernatant was estimated by Sephadex G-100 gel filtration to be about 28000 . Albumin (mol.wt. 68000), peroxidase (mol.wt. 40000), pepsin (mol.wt. 35000) and cytochrome $c$ (mol.wt. 11 700) were used as reference proteins. The mol.wt. of the three preparations of the purified enzyme, as established by polyacrylamide-gel electrophoresis in the presence of sodium dodecyl sulphate, was $29000 \pm 500$ (mean \pm S.D.). Albumin, ovalbumin (mol.wt. 43000), pepsin, trypsin (mol.wt. 23300), myoglobin (mol.wt. 17200) and cytochrome $c$ were used as reference proteins.

\section{Effects of the enzyme on chain termination in fatty acid synthesis}

The incubation system used to test the effects of the purified enzyme on chain termination contained purified fatty acid synthetase and $\left[1-{ }^{14} \mathrm{C}\right]$ acetyl-CoA plus purified acetyl-CoA carboxylase so as to generate rate-limiting amounts of malonyl-CoA. This system synthesized predominantly $C_{4: 0}$ and $C_{14: 0}$ acids plus a varying proportion of $\mathrm{C}_{16: 0}$ (Table 2 , Expt. a); when malonyl-CoA is not rate-limiting, $C_{16: 0}$ is the major product (Carey \& Dils, 1970b).

When albumin $(260 \mu \mathrm{g})$ was added as a control, it increased the rate of fatty acid synthesis and the proportion of $\mathrm{C}_{14: 0}$ synthesized, but did not increase the proportions of medium-chain fatty acids formed (Table 2, Expt. b). This increased rate may be due to a direct effect of albumin on the activity of acetyl-CoA carboxylase or to the removal of unesterified fatty acids synthesized which may inhibit this enzyme.

When $15 \mu \mathrm{g}$ of the three preparations of purified hydrolase (specific activities 305, 1130 and $2010 \mathrm{nmol} /$ min per $\mathrm{mg}$ of protein respectively) was added in the absence of albumin, there was a consistent increase in the proportion of $\mathrm{C}_{4: 0}$ acid synthesized (Table 2, Expts. $a, c, e$ and $k$ ). With 30 and $45 \mu \mathrm{g}$ of the purified hydrolase of specific activity $1130 \mathrm{nmol} / \mathrm{min}$ per $\mathrm{mg}$ of protein, the proportion of $\mathrm{C}_{4: 0}$ acid formed increased further until it was the predominant product (Table 2, Expts. $a, e, g$ and $i$ ). These effects probably reflect the decreased rates of fatty acid synthesis observed.

In the presence of $15 \mu \mathrm{g}$ of the three preparations of the hydrolase with no added albumin, there was a decrease in the proportion of long-chain $\left(C_{14: 0}\right.$ and $\left.\mathrm{C}_{16: 0}\right)$ fatty acids synthesized and an increase in the proportion of medium-chain $\left(\mathrm{C}_{8: 0}\right.$ and $\left.\mathrm{C}_{10: 0}\right)$ acids formed (Table 2, Expts. $a, c, e$ and $k$ ). These changes were related to the units of hydrolase activity added.

The most striking changes were observed when albumin was present in the incubation mixture. When $15 \mu \mathrm{g}$ of the three preparations of purified hydrolase was added, the increase in the proportion of $\mathrm{C}_{4: 0}$ acid synthesized was much less marked (Table 2, Expts. $b$, $d, h$ and $l$ ). This reflected the much higher rates of fatty acid synthesis in the presence of albumin compared with those in its absence. The proportions of medium-chain fatty acids synthesized increased with the units of hydrolase activity added and there was a corresponding decrease in the proportions of longchain fatty acids formed (Table 2, Expts. $b, d, f$ and l). Chain termination at $\mathbf{C}_{8: 0}$ and $\mathbf{C}_{10: 0}$ acids also occurred when $30 \mu \mathrm{g}$ of the purified hydrolase of specific activity $1130 \mathrm{nmol} / \mathrm{min}$ per $\mathrm{mg}$ of protein was added (Expt. $h$ ). However, when the amount of enzyme preparation was increased to $45 \mu \mathrm{g}$, there was a decrease in the proportion of medium-chain acids formed. $\mathrm{C}_{4: 0}$ acid again became the major product, even though the rate of fatty acid synthesis did not decrease substantially (Expt. $j$ ).

The mol.wt. of fatty acid synthetase purified from lactating-rabbit mammary gland is $9.1 \times 10^{5}$ (Carey \& Dils, 1970a), whereas that of the purified hydrolase is 29000 . These values have been used to gain some insight into the relative proportions (on a protein basis) of the two enzymes required for chain termination at $\mathrm{C}_{8: 0}$ and $\mathrm{C}_{10: 0}$ acids in the presence of albumin. When 


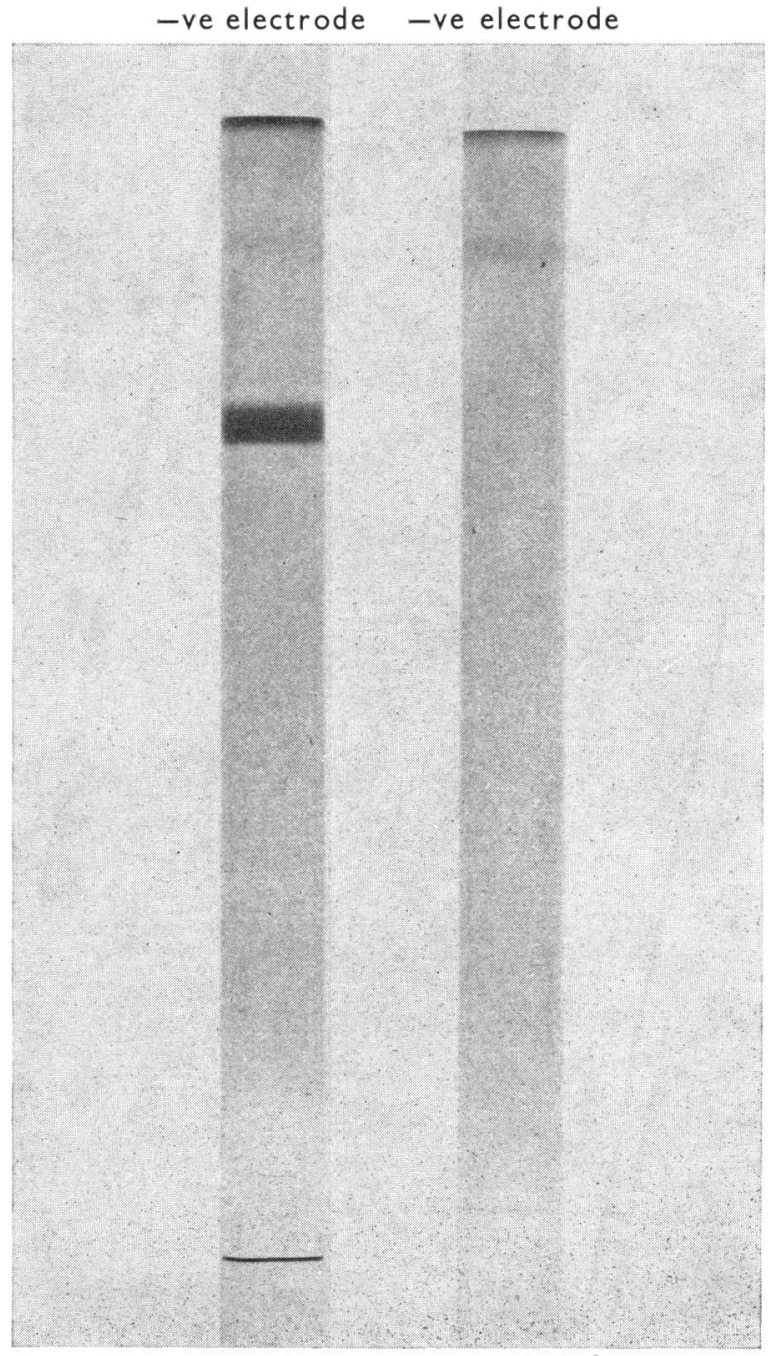

(a)

(b)

\section{EXPLANATION OF PLATE I}

Purity of medium-chain acyl-thioester hydrolase by the criterion of analytical polyacrylamide-gel electrophoresis

(a) Samples of the enzyme ( $6 \mu \mathrm{g}$ of protein) were analysed by polyacrylamide-disc-gel electrophoresis in the presence of sodium dodecyl sulphate on $10 \%$ (w/v) gels (Weber \& Osborn, 1969). Three independent preparations of the enzyme showed the same degree of homogeneity. (b) Control experiments carried out in the absence of enzyme showed a minor band which migrated at about half the rate of that shown by the enzyme. 
Table 2. Effects of purified medium-chain acyl-thioester hydrolase on the proportions of fatty acids synthesized by fatty acid synthetase

The incubation system is described in the Materials and Methods section (under 'Assay of medium-chain acyl-thioester hydrolase activity by chain-length termination in fatty acid synthesis'). The incubations contained fatty acid synthetase purified from lactating-rabbit mammary gland $(218 \mu \mathrm{g}$ of specific activity $1.16 \mu \mathrm{mol}$ of NADPH oxidized/min per mg of protein) and acetyl-CoA carboxylase purified from lactating-rabbit mammary gland (10.5 $\mu \mathrm{g}$ of specific activity $520 \mathrm{nmol}$ of malonyl-CoA formed/min per $\mathrm{mg}$ of protein). The three preparations of purified medium-chain acyl-thioester hydrolase (abbreviated to 'hydrolase' in the Table) and albumin $(260 \mu \mathrm{g})$ were added as shown. Their specific activities are given as $\mathrm{nmol}$ of dodecanoyl-CoA hydrolysed/min per $\mathrm{mg}$ of protein at a substrate concentration of $56 \mu \mathrm{M}$ in the spectrophotometric assay. The rates of incorporation are mean values \pm half the difference between duplicate incubations.

Percentage distribution $(\mathrm{mol} / 100 \mathrm{~mol})$ of radioactivity in fatty acids

\begin{tabular}{|c|c|c|c|c|c|c|c|c|c|}
\hline \multirow[b]{2}{*}{ Expt. } & \multirow[b]{2}{*}{ Addition(s) } & & \multirow{2}{*}{$\begin{array}{l}{\left[1-{ }^{14} \text { C]acetyl-CoA }\right.} \\
\text { (nmol) }\end{array}$} \\
\hline & & $\mathrm{C}_{4: 0}$ & $\mathrm{C}_{6: 0}$ & $\mathrm{C}_{8: 0}$ & $\mathrm{C}_{10: 0}$ & $\mathrm{C}_{12: 0}$ & $\mathrm{C}_{14: 0}$ & $\mathrm{C}_{16: 0}$ & \\
\hline$(a)$ & None & 38 & 12 & 5 & 3 & 6 & 30 & 6 & $27.7 \pm 1.6$ \\
\hline (b) & Albumin & 18 & 6 & 0 & 2 & 6 & 55 & 13 & $44.0 \pm 0.8$ \\
\hline (c) & Hydrolase $(15 \mu \mathrm{g} ;$ specific activity 305$)$ & 64 & 11 & 6 & 8 & 5 & 6 & 0 & $16.4 \pm 1.6$ \\
\hline (d) & $\begin{array}{l}\text { Hydrolase (15 } \mu \mathrm{g} ; \text { specific activity } 305) \\
\text { plus albumin }\end{array}$ & 33 & 7 & 7 & 16 & 13 & 21 & 3 & $35.9 \pm 0.9$ \\
\hline (e) & Hydrolase $(15 \mu \mathrm{g}$; specific activity 1130$)$ & 62 & 11 & 9 & 12 & 4 & 2 & 0 & $18.9 \pm 0.1$ \\
\hline$(f)$ & $\begin{array}{l}\text { Hydrolase (15 } \mu \mathrm{g} ; \text { specific activity } 1130) \\
\text { plus albumin }\end{array}$ & 16 & 4 & 17 & 36 & 17 & 8 & 2 & $43.0 \pm 1.3$ \\
\hline (g) & Hydrolase ( $30 \mu \mathrm{g}$; specific activity 1130$)$ & 78 & 12 & 6 & 4 & $\mathbf{0}$ & $\mathbf{0}$ & $\mathbf{0}$ & $11.0 \pm 0.3$ \\
\hline (h) & $\begin{array}{l}\text { Hydrolase ( } 30 \mu \mathrm{g} \text {; specific activity } 1130) \\
\text { plus albumin }\end{array}$ & 29 & 9 & 26 & 28 & 6 & 2 & 0 & $37.8 \pm 3.4$ \\
\hline (i) & Hydrolase ( $45 \mu \mathrm{g}$; specific activity 1130 ) & 89 & 9 & 1 & 1 & 0 & $\mathbf{0}$ & 0 & $6.4 \pm 0.1$ \\
\hline (j) & $\begin{array}{l}\text { Hydrolase ( } 45 \mu \mathrm{g} \text {; specific activity } 1130) \\
\text { plus albumin }\end{array}$ & 53 & 12 & 23 & 11 & 1 & 0 & 0 & $29.5 \pm 0.3$ \\
\hline$(k)$ & Hydrolase ( $15 \mu \mathrm{g}$; specific activity 2010$)$ & 59 & 18 & 10 & 11 & 2 & $\mathbf{0}$ & 0 & $9.8 \pm 2.0$ \\
\hline (l) & Hydrolase (15 $\mu \mathrm{g}$; specific activity 2010$)$ & 26 & 10 & 20 & 30 & 10 & 3 & 1 & $32.2 \pm 4.4$ \\
\hline
\end{tabular}

Expt.

None

Hydrolase $(15 \mu \mathrm{g}$; specific activity 305$)$

ydrolase (15 $\mu \mathrm{g}$; specific activity 305$)$ plus albumin

$(e)$

ydrolase (1S $\mu \mathrm{g}$; specific activity 1130$)$ plus albumin

Hydrolase ( $30 \mu \mathrm{g}$; specific activity 1130$)$ plus albumin

(i) Hydrolase (45 $\mu \mathrm{g}$; specific activity 1130)

(k) Hydrolase $(15 \mu \mathrm{g}$; specific activity 2010$)$ plus albumin
Total acetate incorporated from $\left[1-{ }^{14} \mathrm{C}\right]$ acetyl-CoA$$
27.7 \pm 1.6
$$

$44.0 \pm 0.8$

$16.4 \pm 1.6$

$35.9 \pm 0.9$

$18.9 \pm 0.1$

$11.0 \pm 0.3$

$32.2 \pm 4.4$ the molar ratio of synthetase to hydrolase was maintained at $1: 0.5$, chain termination was greatest when the two hydrolase preparations with the highest specific activities were used (Table 2, Expts. $d, f$ and l). When increasing amounts of hydrolase of specific activity $1130 \mathrm{nmol} / \mathrm{min}$ per $\mathrm{mg}$ of protein were added, the maximum proportion ( $54 \mathrm{~mol} \%$; Expt. $h$ ) of medium-chain fatty acids synthesized was observed at a molar ratio of synthetase to hydrolase of $1: 1$ (Expts. $f, h$ and $j$ ).

The effects of albumin and the chain termination by the hydrolase shown in Table 2 have been reproduced in other experiments with these and other preparations of the hydrolase.

\section{Properties of the purified enzyme with acyl-CoA esters as model substrates}

Acyl-CoA esters were then used as model substrates for the purified enzyme so as to compare its properties with those of long-chain acyl-CoA hydrolases in other tissues.

Substrate specificity. The critical micellar concentrations of acyl-CoA esters of different chain lengths are not known for the incubation conditions used to assay the purified enzyme. Hence meaningful values for $K_{\mathrm{m}}$ and $V_{\max }$. could not be obtained in these experiments. To avoid this problem of critical micellar concentrations, the specificity of the purified enzyme in the absence of albumin towards acyl-CoA esters of different chain lengths was measured at low substrate concentrations, i.e. $8 \mu \mathrm{M}$ for acyl-CoA esters of chain lengths $\mathrm{C}_{4: 0}-\mathrm{C}_{12: 0}$, and $3 \mu \mathrm{M}$ for acyl-CoA esters of chain lengths $C_{8: 0}-C_{16: 0}$ (Fig. 1).

At both 3 and $8 \mu \mathrm{M}$ substrate, the rate of hydrolysis was greatest with dodecanoyl-CoA. The enzyme did not hydrolyse butyryl-CoA or hexanoyl-CoA at measurable rates. The rates of hydrolysis of octanoyl$\mathrm{CoA}$ and of decanoyl-CoA were about 5 and $50 \%$ respectively of that of dodecanoyl-CoA with all three enzyme preparations. Tetradecanoyl-CoA and hexadecanoyl-CoA were hydrolysed at rates about $60 \%$ and $55 \%$ respectively of that of dodecanoyl-CoA when the enzyme with the highest specific activity was used (preparation c, Fig. 1a). There was little difference in the rate of hydrolysis of fatty acyl-CoA esters of chain lengths $C_{12: 0}-C_{16: 0}$ when the enzyme with the lowest specific activity was used (preparation b, 

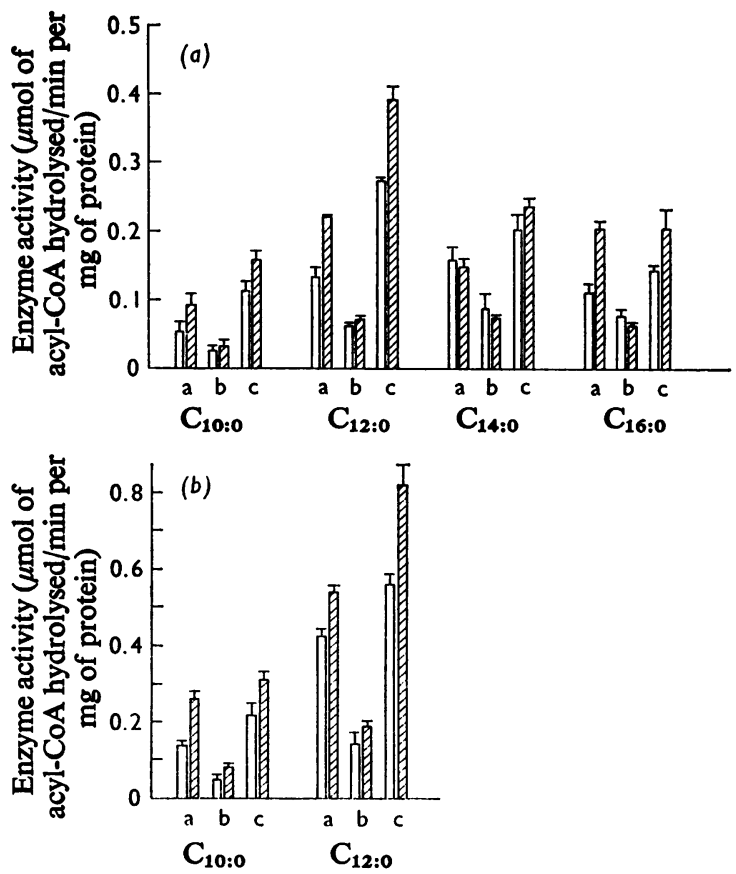

Fig. 1. Specificity of purified medium-chain acyl-thioester hydrolase towards acyl-CoA esters as model substrates

The radiochemical assay used to determine the substrate specificity is described in the Materials and Methods section. In $(a)$ and $(b)$ the substrate concentrations were 3 and $8 \mu \mathrm{M}$ respectively. Three purified enzyme preparations were used. Preparations a, b and c had, respectively, specific activities of 1130,305 and $2010 \mathrm{nmol}$ of dodecanoyl-CoA hydrolysed/min per $\mathrm{mg}$ of protein as determined by the spectrophotometric assay with $56 \mu \mathrm{M}$ substrate (see the Materials and Methods section). The shaded columns are enzyme activity in the presence of $30 \mu \mathrm{g}$ of albumin $/ \mathrm{ml}$ of incubation mixture. The open columns are enzyme activity in the absence of albumin. The error bars are the standard deviations of triplicate incubations.

Fig. 1a). The enzyme was unable to hydrolyse acylcarnitine esters of chain lengths $\mathrm{C}_{4: 0}-\mathrm{C}_{16: 0}$ at concentrations of 3 and $10 \mu \mathrm{M}$.

\section{Properties of the enzyme with dodecanoyl-CoA as model substrate}

Since the purified enzyme showed the highest rate of hydrolysis with dodecanoyl-CoA, this was used as the substrate in the following experiments.

pH-activity curve. The enzyme showed the highest activity at $\mathrm{pH} 7.0-7.5$ towards $8 \mu \mathrm{M}-\left[1-{ }^{14} \mathrm{C}\right]$ dodecanoyl-CoA in $0.1 \mathrm{M}$-potassium phosphate buffer containing $1 \mathrm{~mm}$-EDTA and $1 \mathrm{~mm}$-dithiothreitol.

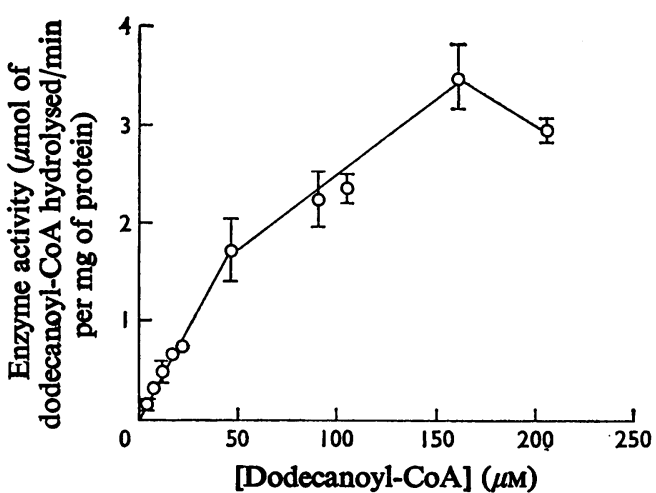

Fig. 2. Effect of substrate concentration on the hydrolysis of dodecanoyl-CoA by medium-chain acyl-thioester hydrolase

The radiochemical assay used is described in the Materials and Methods section. The substrate concentration was varied as shown. The error bars represent the standard deviation of triplicate incubations. Similar results were obtained with all three preparations of the purified enzyme.

Substrate concentration. The rate of hydrolysis of dodecanoyl-CoA increased linearly with substrate concentration up to $45 \mu \mathrm{M}$ (Fig. 2). The rate decreased at higher concentrations, and a slight inhibition was observed at $212 \mu \mathrm{M}$ substrate, though it was difficult to obtain reproducible results at high substrate concentrations. This may be due to the differing extent of micelle formation even though the substrate was preincubated with buffer for $5 \mathrm{~min}$ before the enzyme was added.

Effects of albumin. Fatty acid-poor albumin increased the rate of hydrolysis of dodecanoyl-CoA by the two preparations of the purified enzyme of high specific activity (Fig. 3). The maximum increase occurred with $30 \mu \mathrm{g}$ of albumin $/ \mathrm{ml}$ of incubation mixture; higher concentrations decreased the rate, which may be due to the binding of substrate. This optimum concentration of albumin was found to increase the rate of hydrolysis of all fatty acyl-CoA esters of chain lengths $\mathrm{C}_{8: 0}-\mathrm{C}_{16: 0}$ (except for the $C_{14: 0}$ ester) when the two enzyme preparations of highest specific activity were used (Fig. 1, preparations $a$ and c). However, it did not affect the overall pattern of chain-length specificity.

This stimulatory effect of albumin could have been due to the removal of inhibitory products. Increasing concentrations of unesterified dodecanoic acid were therefore added to the incubation system described in the legend to Fig. 3, except that albumin was omitted from the system containing $8 \mu \mathrm{M}$-dodecanoyl-CoA. 


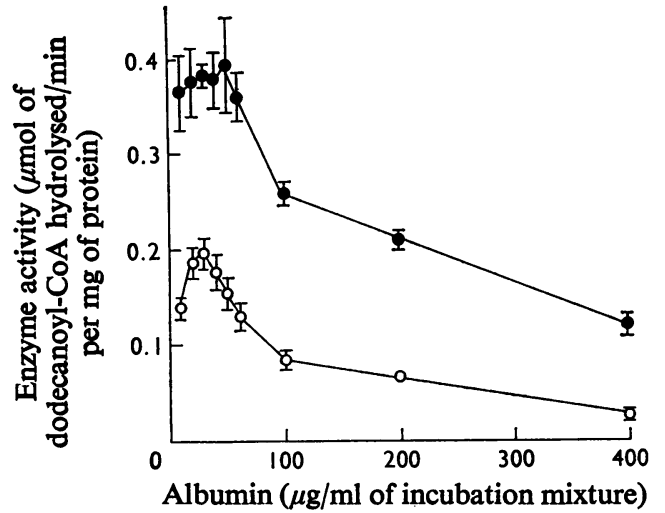

Fig. 3. Effect of albumin on the activity of purified mediumchain acyl-thioester hydrolase towards dodecanoyl-CoA

The radiochemical assay used is described in the Materials and Methods section. Fatty acid-poor albumin was added as shown. The substrate was $3 \mu \mathrm{M}$-dodecanoyl-CoA (O) or $8 \mu \mathrm{M}$-dodecanoyl-CoA (๑). The errors bars represent the standard deviation of triplicate incubations. The purified enzyme preparation had a specific activity of $1130 \mathrm{nmol}$ of dodecanoyl-CoA hydrolysed/min per $\mathrm{mg}$ of protein as determined by the spectrophotometric assay with $56 \mu \mathrm{M}$ substrate (see the Materials and Methods section). Similar results were obtained by using the purified enzyme preparation of specific activity $2010 \mathrm{nmol}$ of dodecanoyl-CoA hydrolysed/min per $\mathrm{mg}$ of protein.

No decrease in the rate of hydrolysis of dodecanoylCoA was observed even when $3 \mathrm{~mm}$-dodecanoic acid was added. This indicates that the effect of albumin is unlikely to be due to the removal of inhibitory products.

\section{Discussion}

Purified fatty acid synthetase from lactating-rabbit mammary gland synthesizes $\mathrm{C}_{4: 0}$ and $\mathrm{C}_{16: 0}$ fatty acids in the presence of optimum concentrations of acetylCoA and malonyl-CoA (Carey \& Dils, 1970b). With the assay system described in Table 2 , there is a constant and rate-limiting generation of malonylCoA. This will limit the probability of chain elongation according to the model of Sumper et al. (1969). If the rate of elongation is decreased sufficiently, $\mathrm{C}_{14: 0}$ should be the predominant fatty acid synthesized according to this model. This is because the rate of hydrolysis of shorter-chain fatty acids by the acylthioester hydrolase of the synthetase is low compared with the rate of elongation. The results in Table 2 show that purified fatty acid synthetase from rabbit mammary gland behaves according to this model. It can also be predicted from the model that mediumchain fatty acids would be synthesized if mediumchain acyl-thioester hydrolase activity was added, which could specifically release these acids from the synthetase.

Preliminary evidence for the occurrence of this chain-terminating enzyme in the cytosol of lactatingrabbit mammary gland (Knudsen et al., 1975) has now been confirmed and the enzyme has been purified. When added to a system which is synthesizing shortand long-chain fatty acids from rate-limiting amounts of malonyl-CoA the behaviour predicted from the model of Sumper et al. (1969) is observed. That the decrease in the chain length of the synthesized fatty acids is related to the amount of medium-chain acylthioester hydrolase activity added can be seen from the results given in Table 2 . The purified mediumchain acyl-thioester hydrolase must therefore be able to use as substrates medium-chain acyl residues which are bound to synthetase, probably as acyl-carrier protein derivatives.

It is not known whether the effects of albumin on chain termination (Table 2) are due to changes in protein concentration or to the removal of unesterified fatty acids synthesized, which are likely to inhibit acetyl-CoA carboxylase.

The results presented here may well explain the synthesis of $\mathrm{C}_{8: 0}$ and $\mathrm{C}_{10: 0}$ fatty acids by lactatingrabbit mammary gland in vivo (Carey \& Dils, 1972) and in vitro (Strong \& Dils, 1972). The conditions required for the purified hydrolase to function in chain termination are the generation of low and ratelimiting amounts of malonyl-CoA. Acetyl-CoA carboxylase is thought to be the rate-limiting enzyme of fatty acid biosynthesis de novo in a number of tissues [see Numa (1974) for review]. Smith \& Abraham (1970) have found the activity of fatty acid synthetase to be 2.5 times that of acetyl-CoA carboxylase in extracts of lactating-rat mammary gland when the enzymes were assayed under optimum conditions. This ratio is 4.35 in the microsomal plus particle-free supernatant fraction of homogenates of lactating-rabbit mammary gland (Smith et al., 1966). Conditions favourable for the medium-chain acylthioester hydrolase to function in chain termination could therefore occur in lactating mammary gland in vivo.

\section{Comparison with long-chain acyl-CoA hydrolases}

Molecular weight. The mol.wt. of long-chain acylCoA hydrolase isolated from seven tissues from the rat was 50000 as determined by sucrose-densitygradient centrifugation. However, the mol.wt. of the enzyme from rat heart, spleen and blood was about 100000 as estimated by Sephadex G-100 gel filtration (Kurooka et al., 1972). Long-chain acyl-CoA hydrolase from bovine brain showed two peaks of activity when chromatographed on Sephadex G-200 at $2^{\circ} \mathrm{C}$. This is due to the dissociation of a dimer of mol.wt. 96000 into monomers of mol.wt. 46000 
(Anderson \& Erwin, 1971). This formation of a dimer could explain the mol.wt. of 100000 found for the enzyme in rat heart, spleen and blood by gel filtration.

The mol.wt. of purified medium-chain acylthioester hydrolase from lactating-rabbit mammary gland $(29000)$ is similar to that of the subunits (30000) of the higher-mol.wt. form $(90000-117000)$ of long-chain acyl-CoA hydrolase from $E$. coli (Barnes et al., 1970; Bonner \& Bloch, 1972). This latter enzyme hydrolyses palmitoyl-acyl-carrier protein and might therefore be involved in the synthesis of longchain fatty acids. The mol.wt. of the medium-chain acyl-thioester hydrolase is somewhat higher than that of a second long-chain acyl-CoA hydrolase from $E$. cali (22000). It has been shown that this second hydrolase from $E$. coli participates in chain-length termination leading to the synthesis of long-chain unesterified fatty acids (Barnes \& Wakil, 1968). The most interesting similarity is between the mol.wt. of the medium-chain acyl-thioester hydrolase and the long-chain acyl-thioester hydrolase (32000), which can be cleaved from fatty acid synthetase purified from lactating-rat mammary gland by proteolytic hydrolysis (Smith et al., 1976; Agradi et al., 1976).

\section{Substrate specificity}

The substrate specificity of purified medium-chain acyl-thioester hydrolase from rabbit mammary gland towards acyl-CoA esters as model substrates determined at low substrate concentrations showed that the enzyme has the highest activity towards dodecanoyl-CoA (Fig. 1), but substantial activity towards decanoyl-CoA. This specificity differs from that of the low-molecular-weight enzyme from $E$. coli, which shows maximum activity towards tetradecanoyl$\mathrm{CoA}$ and hexadecanoyl-CoA but very low activity towards dodecanoyl-CoA and shorter-chain acylCoA esters (Barnes \& Wakil, 1968). The highmolecular-weight enzyme from $E$. coli shows increasing hydrolytic activity with increasing chain length of acyl-CoA esters, with maximum activity towards hexadecanoyl-CoA and octadecanoyl-CoA (Barnes et al., 1970). The mammalian enzymes show a wide specificity towards medium- and long-chain acyl-CoA esters, which varies with the tissue from which they were isolated (Anderson \& Erwin, 1971; Kurooka et al., 1972). However, comparison with mammalian enzymes is difficult, since their substrate specificities have been determined by estimating $K_{m}$ and $V_{\max }$. values which are doubtful value, owing to micellar formation by the substrates.

\section{Effects of albumin}

The effect of albumin in increasing the rate of hydrolysis of acyl-CoA esters by the high-specificactivity preparations of medium-chain acyl-thioester hydrolase (Fig. 1) is unlikely to be due to the removal of inhibitory unesterified fatty acids formed during hydrolysis. High concentrations of dodecanoic acid did not affect the activity of the enzyme when albumin was omitted from the incubation system. Though Barnes \& Wakil (1968) found that albumin increased the activity of the low-molecular-weight enzyme from $E$. coli, they used a high concentration $(14.4 \mu \mathrm{M})$ of hexadecanoyl-CoA as substrate. The albumin could therefore have prevented the inhibition of the enzyme by substrate in the micellar form. This is unlikely to be the explanation here, since the increase in activity was more pronounced at the lower substrate concentration (Fig. 3). The lack of effect of albumin when the purified enzyme of low specific activity was used could be due to the high concentration $(4 \mu \mathrm{g} / \mathrm{ml})$ of enzyme protein used compared with that when the high-specific-activity enzyme was used $(1 \mu \mathrm{g} / \mathrm{ml})$. If so, this would indicate a protein-concentration effect.

It is not clear whether the effect of albumin in the chain-termination assay (Table 2) is related to its effects on hydrolase activity when acyl-CoA esters are used as model substrates (Figs. 1 and 3).

\section{Summary}

In summary, the presence of medium-chain acylthioester hydrolase activity in extracts of lactatingrabbit mammary gland explains, at least in part, previous reports (Carey \& Dils, 1973a,b; Strong et al., 1973; Knudsen, 1976) which indicated an unidentified factor(s) in these extracts which controlled chain termination.

We thank Miss Annelise W. Anderson and Mr. Erling Knudsen for skilled technical assistance, and the Wellcome Trust for travel grants to R. D. The Science Research Council of Great Britain provided a studentship for S. C., who also received a Boehringer Mannheim Travelling Fellowship.

\section{References}

Agradi, E., Libertini, L. \& Smith, S. (1976) Biochem. Biophys. Res. Commun. 68, 894-900

Anderson, A. D. \& Erwin, V. G. (1971) J. Neurochem. 18, 1179-1186

Andrews, P. (1970) Methods Biochem. Anal. 18, 1-54

Barnes, E. M. \& Wakil, S. J. (1968) J. Biol. Chem. 243, 2955-2962

Barnes, E. M., Swindell, A. C. \& Wakil, S. J. (1970) J. Biol. Chem. 245, 3122-3128

Bar-Tana, J., Rose, G. \& Shapiro, B. (1971) Biochem. J. 122, 353-362

Bonner, W. M. \& Bloch, K. (1972) J. Biol. Chem. 247, 3123-3133

Carey, E. M. \& Dils, R. (1970a) Biochim. Biophys. Acta 210, 371-387

Carey, E. M. \& Dils, R. (1970b) Biochim. Biophys. Acta 210, 388-399 
Carey, E. M. \& Dils, R. (1972) Biochem. J. 126, 10051007

Carey, E. M. \& Dils, R. (1973a) Comp. Biochem. Physiol. B44, 989-1000

Carey, E. M. \& Dils, R. (1973b) Biochim. Biophys. Acta 306 156-167

Dole, V. P. (1956) J. Clin. Invest. 35, 150-154

Knudsen, J. (1972) Biochim. Biophys. Acta 280, 408-414

Knudsen, J. (1976) Comp. Biochem. Physiol. B53, 3-7

Knudsen, J. \& Dils, R. (1975) Biochem. Biophys. Res. Commun. 63, 780-785

Knudsen, J., Clark, S. \& Dils, R. (1975) Biochem. Biophys. Res. Commun. 65, 921-926

Kurooka, S., Hosoki, K. \& Yoshimura, Y. (1972) J. Biochem. (Tokyo) 71, 625-634

Lowry, O. H., Rosebrough, N. J., Farr, A. L. \& Randall, R. J. (1951) J. Biol. Chem. 193, 265-275

Manning, R., Dils, R. \& Mayer, R. J. (1976) Biochem. J. 153, 468-469

Means, G. E. \& Feeney, R. E. (1971) Chemical Modification of Proteins, Holden-Day, San Francisco
Numa, S. (1974) Rev. Physiol. 69, 53-96

Pullman, M. E. (1973) Anal. Biochem. 54, 188-198

Sánchez, M., Nicholls, D. G. \& Brindley, D. N. (1973) Biochem. J. 132, 697-706

Smith, S. \& Abraham, S. (1970) J. Biol. Chem. 245, 3209-3217

Smith, S., Easter, D. J. \& Dils, R. (1966) Biochim. Biophys. Acta 125, 445-455

Smith, S., Agradi, E., Libertini, L. \& Dileepan, K. N. (1976) Proc. Natl. Acad. Sci. U.S.A. 73, 1184-1188

Stadtman, E. R. (1957) Methods Enzymol. 3, 931-941

Stern, I. \& Shapiro, B. (1956) J. Clin. Pathol. 6, 158-169

Strong, C. R. \& Dils, R. (1972) Comp. Biochem. Physiol. $B 43,643-652$

Strong, C. R., Carey, E. M. \& Dils, R. (1973) Biochem. J. 132, 121-123

Sumper, M., Oesterhelt, D., Riepertinger, C. \& Lynen, F. (1969) Eur. J. Biochem. 10, 377-387

Vagelos, P. R. (1974) Biochem. Ser. One 4, 99-140

Weber, K. \& Osborn, M. (1969) J. Biol. Chem. 244, $4406-4412$ 